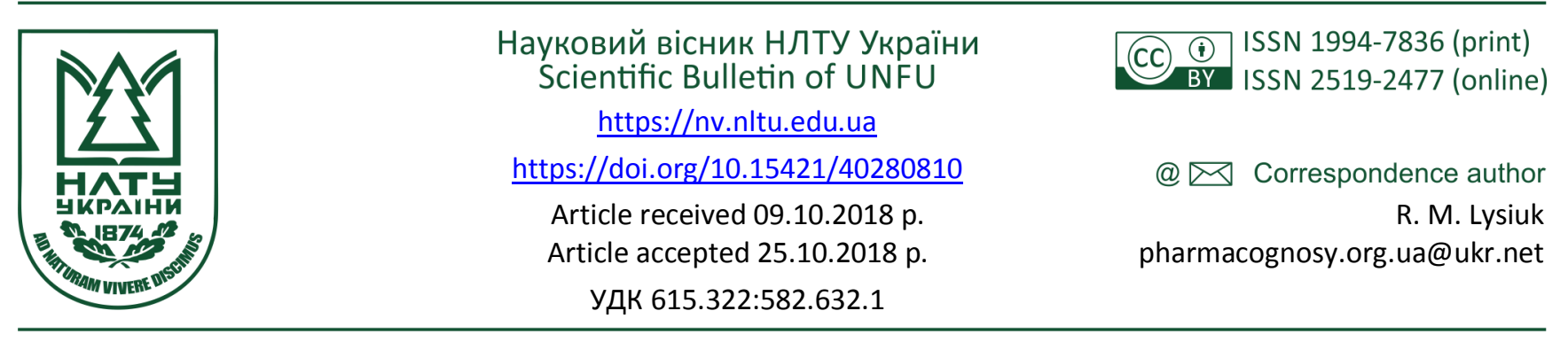

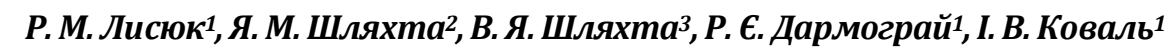

${ }^{1}$ Львівський начіональний медичний університет ім. Данила Галицьького, м. Львів, Украӥна ${ }^{2}$ Національний університет "Львівська політехніка", м. Львів, Україна ${ }^{3}$ Регіональний ландшафтний парк "Знесіння", м. Львів, Украӥна

\title{
ЛИСТЯ ВИДІВ РОДУ ЛІЩИНА ЯК ДЖЕРЕЛА ЦІННОЇ РОСЛИННОЇ СИРОВИНИ
}

Досліджено перспективну рослинну субстанцію - листя ліщини, яке є важливим джерелом фенольних сполук і таксанів та має значний ресурсний потенціал в Україні. Екстракти природних антиоксидантів, отриманих із супутньої сировини плодів фундука, можна використовувати як нутріцевтики, харчові добавки, фармацевтичні або косметичні субстанції; таксол і таксани є відомими протираковими сполуками. Серед близько 10 видів роду Ліщина, інтродукованих у ботанічних садах та дендрологічних парках України, тільки два виявилися перспективними як у ботанічному, так і у фармацевтичному аспектах. Наведено наукові дані щодо ресурсних і морфо-біологічних характеристик ліщини звичайної та деревовидної, їх хімічного складу, фармакологічної активності; оцінено актуальний стан й перспективи медичного застосування. Проведено порівняльний аналіз еколого-фітоценотичних особливостей ліщини звичайної та ліщини деревовидної, актуального стану і перспектив інтродукції цих видів в Україні. Представлені наукові дані щодо багатого хімічного складу та фармакологічної активності листя ліщини свідчать про перспективність подальших досліджень цього виду лікарської рослинної сировини та можна їх використати для оптимізації їх застосування у разі серцево-судинних, гастроентерологічних та урологічних захворювань та опрацювання критеріїв стандартизації для цих рослинних субстанцій.

Ключові слова: ліщина звичайна; ліщина деревовидна; фенольні сполуки; активність; застосування.

Вступ. Серед видів роду Ліщина (Corylus), що належить до підродини Coryloideae родини Betulaceae (Takhtajan, 2009), найпоширенішою є ліщина звичайна (C.avellana L.), компонент наших лісів. Усього цей рід налічує близько 20 видів, які поширені в Євразії та Північній Америці. У садах і парках найчастіше культивуються три види: Corylus avellana, C. colurna L. і C. maxi$m a$ Mill.; близько 10 видів роду інтродуковано в ботанічних садах та дендрологічних парках України (Olshanskyi, 2014). Однак тільки два види роду виявилися перспективними як у ботанічному, так і у фармацевтичному аспектах (Lysiuk \& Shliakhta, 2014).

Викладення основного матеріалу. Протягом останніх двох десятиріч значно зросло зацікавлення листям ліщини звичайної (ЛЛЗ) після ідентифікації у складі сировини та калусних культур різних органів цього виду таксолу і таксанів - відомих протиракових сполук (Bestoso et al., 2006; Ottaggio et al., 2008; Gallego Palacios, 2015). ЛЛЗ вважають перспективним джерелом антиоксидантів (Amaral et al., 2010; Shahidi et al., 2007) відзначають, що екстракти природних антиоксидантів, отриманих із супутньої сировини плодів фундука, можна використовувати як нутріцевтики, харчові добавки, фармацевтичні або косметичні субстанції. У ЛЛЗ встановлено найвищі показники загального вмісту фенолів та загальної антиоксидантної активності, порівняно 3 оболонкою плодів, шкіркою, зеленим листковим покриттям і ядром ліщини (Amaral et al., 2010).

Деревина ліщини блискуча, гнучка, пружна, добре полірується. Ї̈і цінують у меблевому виробництві та виготовленні дрібних виробів; з неї виготовляють побутові, столярні й токарні вироби. Великоплідні сорти (фундук) мають великий попит у харчовій промисловості (Belgard, 1984; Lysiuk \& Shliakhta, 2014).

До важливих морфо-біологічних особливостей ліщини звичайної варто віднести такі відмінності: високий багатостовбурний розлогий кущ, який виростає до 5 м заввишки, пагони і листя якого $є$ опушеними. Форма листка майже округла, на верхівці різко звужена; довжина - 6-12 см, ширина $-5-9$ см; на коротких товстих черешках. Окремі листки на ювенальних пагонах можуть досягати й більших розмірів. Дрібні тичинкові

\section{Інформація про авторів:}

Лисюк Роман Миколайович, асистент, кафедра фармакогнозії і ботаніки. Email: pharmacognosy.org.ua@ukr.net; https://orcid.org/0000-0003-0961-2970

Шляхта Янош Мигальович, канд. с.-г. наук, доцент, ботанычний сад Ну "лП". Email: pharmacognosy.org.ua@ukr.net

Шляхта Василь Яношович, дендролог-паркознавець. Email: pharmacognosy.org.ua@ukr.net

Дармограй Роман Євдокимович, канд. фармац. наук, доцент, завідувач кафедри фармакогнозії і ботаніки. Email: kaf_pharmacognosy@meduniv.lviv.ua

Коваль Ірина Вікторівна, студентка, кафедра фармакогнозії і ботаніки. Email: kaf_pharmacognosy@meduniv.lviv.ua

Цитування за ДСтУ: Лисюк Р. М., Шляхта Я. М., Шляхта В. Я., Дармограй Р. Є., Коваль І. В. Листя видів роду ліщина як джерела цінної рослинної сировини. Науковий вісник НЛтУ України. 2018, т. 28, № 8. С. 51-55.

Citation APA: Lysiuk, R. M., Shliakhta, Ya. M., Shliakhta, V. Ya., et al. (2018). Leaves of Corylus Spp. as sources of valuable herbal substances. Scientific Bulletin of UNFU, 28(8), 51-55. https://doi.org/10.15421/40280810 
квіти, 3 яких виступають червонуваті лусочки, з'являються навесні наступного року. Плоди - горіхи, зібрані по 2-4(5), майже кулясті, до 1,8 см завдовжки і до 1,5 см завширшки. Цвіте ліщина звичайна у квітні, плодоносить у серпні - вересні (Kosenko, 2002; Kokhno et al., 2002).

За фітоценотичною сутністю цей вид ліщини в умовах України, головним чином Правобережжя, виступає едифікатором мегатрофності лісорослинних умов. Тому зростає тут повсюдно, особливо у свіжих та вологих дібровах, де $\epsilon$ характерним їх компонентом. В оптимальних екологічних умовах утворює густі зарості підліску.

Перспективні особини ліщини можна легко розмножувати способом згинання та часткового прикопування молодих пагонів (довжиною до 1 м) навесні; уже восени формується укорінений саджанець, який варто відрізати від основного дерева (Kosenko, 2002).

Інший вид - ліщина деревовидна, або ведмежий гоpix, ймовірно, не менш цінна, ніж попередній вид, проте значного поширення в Україні все ще не набула; хоча іiі вивчення на наших теренах достатньо відоме. Загальне потепління клімату сприяє його розвитку, адже це представник Кавказу, Північного Ірану та Балкан, що інколи потерпав від морозів.

Морфо-біологічною особливістю ліщини деревовидної є нетипова життєва форма. Це ошатне дерево висотою до 25 м зі широкоовальною кроною. Кора стовбура cipa, глибокотріщинувата. Пагони жовто-сірі, щетинисто-волосисті. Листки округлі, яйцеподібні або овальні, 7-12 см завдовжки і 5-10 см завширшки, опушені; на пагонах розміщені почергово, по краях двічі зубчасті, 3 перистим жилкуванням, як і в попереднього виду. Плоди - горішки 3 дерев'янистими шкаралупами, товстішими, ніж у ліщини звичайної; зібрані по 4-9, об'єднані кошлатим м'ясистим перикарпієм (супліддям). Цвіте у квітні, плодоносить у серпні - вересні. У врожайні роки масивним супліддям обвішана вся крона. А. Жила та М. Гузь зауважують, що квіти ліщини деревовидної потребують перехресного запилення, оскільки під час самозапилення високоякісних за смаковими властивостями та життєздатних горіхів дерева не продукують (Zhyla \& Huz, 2011, 2012).

Еколого-фітоценотичні особливості медвежого горіха дещо подібні до ліщини звичайної, однак потенційні можливості його є значно більшими. На сьогодні відомо, що ліщина деревовидна придатна для створення високодекоративних у будь-яку пори року алейних насаджень, для яких характерна відносна швидкорослість до досягнення певної висоти (зазвичай 10-13 м), довговічність, відсутність шкідників. До того ж є можливість використання таких дерев для збирання цінної горіхоплідної сировини; адже дерева в таких насадженнях починають швидше і рясніше плодоносити, порівняно 3 тими, які ростуть у лісових умовах. Це підтверджується ii участю у міських насадженнях низки міст Європи, зокрема Братислави та Відня.

Хоча в культурі на території Україні цей вид з XVIII ст. і має велику цінність, особливо для зеленого будівництва, все ж належного поширення досі не набув. Про це свідчать і наші обстеження населених міст західних регіонів під час проведення технічної інвентаризації (Звіти про виконання НДР за 2002-2014 рр. Виконавці: Шляхта Я. М., Шляхта В. Я.).
Листя ліщини звичайної містять полісахариди, жирні кислоти, амінокислоти, вітаміни (С, РР, каротиноїди, токофероли, групи В), органічні кислоти, дубильні речовини $(7,7-11,6 \%)$, флавоноїди (кверцетин, мірицетин, кемпферол та їхні глікозиди; проантоціаніди), гідроксикоричні кислоти, альдегіди (гексен-2-аль-1), ефірну олію, алкалоїди, мінеральні сполуки, зокрема Fe, K, Mg та I (Hrodzinskyi, 1992; Efremov \& Shreter, 1996; Rusu et al., 1999; Popova \& Litvinenko, 2008; Iusifova et al., 2014; Harna et al., 2016). Серед мікроелементів у листі ліщини звичайної також виявлено $\mathrm{Al}, \mathrm{B}, \mathrm{Ba}, \mathrm{Cr}, \mathrm{Cu}, \mathrm{Mn}$, $\mathrm{V}, \mathrm{Zn}$. Варто звернути увагу на значний вміст у сировині Mn $\left(208,6^{ \pm 2,1}\right.$ мг/кг сухої маси) (Szentmihályi, Marczal $\&$ Then, 2006).

Мовсумов и др. (Movsumov, Iusifova \& Garaev, 2013) ідентифікували у ЛЛЗ тритерпеновий спирт бетулін і низку флавоноїдів: мірицетин, кверцетин, кверцитрин, кемпферол, афзелін. ЛЛЗ містить 16 жирних кислот, серед яких домінуючими за вмістом є ліноленова, пальмітинова, лінолева. У ЛЛЗ, зібраному в Україні, міститься $1,52^{ \pm 0,02} \%$ гідроксикоричних кислот (у перерахунку на хлорогенову кислоту), 1,52 $\pm 0,01 \%$ флавоноїдів (гіперозид), $1,23^{ \pm 0,04} \%$ дубильних речовин (танін), $2,27^{ \pm 0,01} \%$ катехінів ((-)-катехін). Найвищий вміст суми катехінів 4,22 \% встановлено у ЛЛЗ сорту "Дар Павленко". Вміст (на абсолютно суху сировину) суми органічних кислот у ЛЛЗ у перерахунку на яблучну кислоту становив для: свіжо зібраної сировини - 2,604 ${ }^{ \pm 0,15} \%$, повітряно-сухої - $0,896^{ \pm 0,024} \%$; аскорбінової кислоти $-0,200^{ \pm 0,018} \%$ та $0,058^{ \pm 0,004} \%$, відповідно (Khvorost, 2006).

Проведені дослідження динаміки накопичення суми окислюваних фенолів, флавоноїдів та дубильних речовин ЛЛ3 (Khvorost, 2006) дали змогу встановити оптимальні терміни для заготівлі листя - початок травня кінець липня (враховуючи накопичення флавоноїдів), протягом усього вегетаційного періоду (щодо вмісту решти груп фенольних сполук), що можна враховувати під час встановлення термінів проріджування культивованих ліщин.

Фенольний склад 93 зразків (19 сортів ліщини, зібраних протягом 3 років у двох географічних місцях на півночі Португалії) було досліджено для оцінки впливу генетичних та едафокліматичних чинників, а також сезонної динаміки (з травня по вересень) накопичення фенольних сполук у чотирьох сортах ліщини звичайної, заготовлених в однакових сільськогосподарських, географічних та кліматичних умовах. Аналіз ЛЛЗ показав, що сировина є багатим джерелом фенольних сполук, оскільки вміст загальних фенолів змінювався від 2,5 до 30,5 г/кг. Збільшення загального вмісту фенолів спостерігалися 3 травня по липень, у серпні їх вміст різко зменшувався, а у вересні відзначили нове зростання. У всіх сортів ліщини звичайної найвищий вміст суми фенольних сполук встановлено у липні (Amaral et al., 2010). За кількісним вмістом серед ідентифікованих фенольних сполук переважали мірицетин-3-рамнозид, кверцетин-3-рамнозид, 5-кофеїлхінна кислота. Іншими 6 мінорними компонентами фенольної фракції є 3-кофеїлхінна кислота, кофеїлвинна кислота, р-кумароілвинна кислота, мірицетин-3-гексозид, кверцетин-3-гексозид, кемпферол-3-рамнозид (Zhyla \& Huz, 2012).

Під час дослідження листя ліщини звичайної як компонента настойки "Венотон" (Kutsenko \& Ruban, 2013) 
встановлено такі показники кількісного вмісту: екстрактивних речовин - 35,44 $4^{ \pm 0,82} \%$, суми флавоноїдів у перерахунку на рутин $-2,54^{ \pm 0,05} \%$, окислювальних поліфенолів - 7,71 ${ }^{ \pm 0,06} \%$. Внаслідок ВЕТШХ аналізу в капсульованій лікарській формі 3 сухим екстрактом Corylus avellana були ідентифіковані рутин, кверцитрин, неохлорогенова та хлорогенова кислоти (Blyznyuk, Prokopenko \& Gergiyants, 2016). Рідкий екстракт (1:1) ЛЛ3 містить $20 \%$ флавонів, $16 \%$ проантоціанідинів (продельфінідин), 56 \% танінових поліфенолів (Rusu et al., 1999).

Основними групами біологічно активних речовин (БАР) фенольної структури листя ліщини ведмежої $\epsilon$ флавоноїди, дубильні речовини та діарилгептаноїди. У складі фенольної фракції листя ліщини ведмежої на особливу увагу заслуговують флавон-3-оли та гідроксикоричні кислоти. Серед флавоноїдів найбільший вміст характерний для кверцетин-3-0-рамнозиду. У складі листя наявні й інші глікозиди кверцетину, а також мірицитину та кемпферолу (Riethmüller, 2016).

Галенові препарати листя ліщини звичайної (Corylus avellana L.) використовують у традиційній медицині для лікування варикозного розширення вен, симптомів геморою, виразкових та ЛОР-інфекцій завдяки судинозвужувальним та кровоспинним властивостям (Amaral et al., 2010).

Настої та відвари ЛЛЗ застосовуються під час лікування захворювань серцево-судинної системи завдяки іiї протинабряковим, венотонізувальним, протиатеросклеротичним, судинозміцнювальним, коронаролітичним, гіпотензивним, антиоксидантним властивостям. Окрім цього, препарати ліщини мають гепатопротекторні, противиразкові, антимікробні, в'яжучі та ранозагоювальні ефекти (Rusu et al., 1999; Popova \& Litvinenko, 2008; Kalenichenko \& Maloshtan, 2016; Mota Ana, 2016).

Листя ліщини (Folia Coryli) входить до складу зареєстрованого лікарського засобу - настойки Венотон ${ }^{\circledR}$, що застосовують у медичній практиці як венотонізувальний, капіляропротекторний, антиексудативний, протизапальний та протинабряковий засіб (Kokhno et al., 2002).

Завдяки судинозвужувальним властивостям препаратів листя ліщини звичайної, вживання їх всередину у формі настою рекомендовано при розширених венах, перифлебітах, виразках гомілки та капілярних геморагіяx (Hrodzinskyi, 1992; Movsumov, Iusifova \& Garaev, 2013; Iusifova et al., 2014; Mota Ana, 2016). Окрім зазначених випадків, препарати ліщини звичайної у народній медицині широко використовують у разі захворювань печінки і нирок, також як засіб, що збуджує апетит (Hrodzinskyi, 1992); внаслідок гострого і хронічного простатитах, аденоми простати (Efremov \& Shreter, 1996), для лікування кишкових захворювань, анемії, авітамінозів, рахіту (Movsumov, Iusifova \& Garaev, 2013).

Відвар ЛЛЗ застосовують як сечогінне, при катарах кишок, хворобах печінки, для полоскання горла, додають у ванни при геморої та захворюваннях шкіри, а в болгарській медицині- у разі гіпертрофії простати. Відвар призначають для посилення тонусу венозних кровоносних судин та капілярів, зменшення їх проникності, внаслідок кровотечах із ясен. Для мазі з ЛЛЗ встановлено протиракову дію (Lysiuk \& Shliakhta, 2014).

У болгарській народній медицині рекомендують використовувати листя ліщини ведмежої для лікування гіпертонії легкої і важкої форми, а також під час збіль- шення простати. БАР рослинної субстанції помірно знижують артеріальний тиск, потенціюють гіпотензивний ефект бета-адреноблокаторів, розширюють коронарні судини; виявляють заспокійливу дію на центральну нервову систему, а також противиразкову активність (Petkov, 1988). Для ЛЛЗ експериментально підтверджено протимікробну, антиоксидантну (Oliveira et al., 2007), протидизентерійну, протигрибкову та ранозагоювальну активності (Fraisse et al., 1999; Amaral et al., 2010)

Екстракт ЛЛЗ у дозі 25 мг/кг в умовах експериментального тромбофлебіту периферичних судин проявляє судинозміцнювальні, антикоагулянтні та протизапальні властивості; комплекс біологічно активних речовин зменшує застій у венозній частині капілярів і накопичення рідини в тканинах, покращує відтік лімфи та венозний кровообіг, знижує проникність судинних стінок і має капілярозміцнювальну дію (Iusifova et al., 2014). Для густого екстракту ЛЛЗ встановлено антикоагулянтну, мембраностабілізуючу та протизапальну активність (Kalenichenko \& Maloshtan, 2016). Екстракт ЛЛЗ має певний захисний ефект під час токсикозі, викликаному тетрахлорметаном, зокрема знижує гепатоцитоліз на $25 \%$, а також стеатоз та інші гістологічні ураження (Rusu et al., 1999), повертає до норми активність деяких ферментів (Rusu et al., 2005).

Антибіотичну активність щодо грампозитивних та грамнегативних бактерій продемонстровано для екстрактів листя ліщини ведмежої (Ceylan, Sahin \& Avaz, 2013). Експериментально встановлено, що флавоноїдна фракція листя ліщини ведмежої - сильний антиоксидант (діє активніше, ніж препарати порівняння тролокс та аскорбінова кислота) (Benov \& Georgiev, 1994; Riethmüller, 2016), є інгібітором пероксидних процесів у мозку і печінці (Kosenko, 2002), а також гепатопротекторним засобом (Radev et al., 1997).

Висновки. Наведені наукові дані щодо багатого хімічного складу та фармакологічної активності листя ліщини свідчать про перспективність подальших досліджень цієї сировини. Ми вивчали особливості накопичення різних класів фенольних сполук та інших цінних груп біологічно активних речовин у листі рослин роду Ліщина, заготовленому в західних областях України, для подальшого опрацювання критеріїв стандартизації для цих рослинних субстанцій і оптимізації застосування у разі серцево-судинних, гастроентерологічних та урологічних захворювань.

\section{Перелік використаних джерел}

Amaral, J. S., Valentao, P., Andrade, P. B., Martins, R. C., \& Seabra, R. M. (2010). Phenolic composition of hazelnut leaves: Influence of cultivar, geographical origin and ripening stage. Scientia Horticulturae, 126, 306-313. https://doi.org/10.1016/j.scienta.2010.07.026

Belgard, A. L. (Ed.). (1984). Opredilitel rastenii lesov USSR. Kyiv: Vishha shkola. Golovnoe izd-vo, 343 p. [In Russian].

Benov, L., \& Georgiev, N. (1994). The antioxidant activity of flavonoids isolated from Corylus colurna. Phytotherapy Res, 8, 92-94. https://doi.org/10.1002/ptr.2650080208

Bestoso, F., Ottaggio, L., Armirotti, A., Balbi, A., Damonte, G., Degan, P., Mazzei, M., Cavalli, F., Ledda, B., \& Miele, M. (2006). In vitro cell cultures obtained from different explants of Corylus avellana produce taxol and taxanes. BMC Biotechnol, 6(45), 123-128. https://doi.org/10.1186/1472-6750-6-45

Blyznyuk, N., Prokopenko, Y., \& Gergiyants, V. (2016). Development of methods for determination of phenolic acids and flavonoids in capsules containing Corylus avellana L. dry extract. Journal Sci- 
enceRise, $2,4(19)$ https://doi.org/10.15587/2313-8416.2016.61495

Ceylan, O., Sahin, M. D., \& Avaz, S. (2013). Antibacterial activity of Corylus colurna L. (Betulaceae) and Prunus divaricata Ledep. subsp. divaricata (Rosaceae) from Usak, Turkey. Bulg J Agric Sci, 19, 1204-1207.

Efremov, A. P., \& Shreter, A. I. (1996). Travnik dlia muzhchin. Moscow: Asadal, 352 p. [In Russian].

Fraisse, D., Carnat, A., Carnat, A. P., \& Lamaison, J. L. (1999). Standardization of the hazel leaf. Annales Pharmaceutiques Francaises, 57, 406-409.

Gallego Palacios. (2015). A. Corylus avellana: a new biotechnological source of anticancer agents. Doct. Diss. Universitat Pompeu Fabra, Barcelona, $246 \mathrm{p}$.

Harna, S. V., Vladymyrova, I. M., Burd, N. B., et al. (2016). Suchasna fitoterapiia. Kharkiv: Publishing "Drukarnia Madryd", 580 p. [In Ukrainian].

Hrodzinskyi, A. M. (Ed.). (1992). Likarski roslyny: Entsyklopedychnyi dovidnyk. Kyiv: Vydavnytstvo "Ukrainska Entsyklopediia" im. M. P. Bazhana, Ukrainskyi vyrobnycho-komertsiinyi tsentr "Olimp", 544 p. [In Ukrainian].

Iusifova, D. Iu., Maloshtan, L. N., \& Shatalova, O. M. (2014). Farmakologicheskoe izuchenie ekstrakta iz listev leshhiny obyknovennoi na modeli tromboflebita peryferycheskykh sosudov ukha krolyka. Ukrainskyi biofarmatsevtychnyi zhurnal, 6(35), 47-50. [In Russian].

Kalenichenko, A. S., \& Maloshtan, L. N. (2016). Skriningovoe issledovanie antikoaguliantnoi, membranostabiliziruiushhei i protivovospalitelnoi aktivnosti gustogo ekstrakta iz listev leshhiny obyknovennoi. Farmakologiia ta likarska toksikologiia, 2(48), 43-48. [In Russian].

Khvorost, O. P. (2006). Farmakognostichne vivchennia roslin poriad$\mathrm{ku}$ berezotcviti ta otrimannia novikh biologichno aktivnikh substantcii riznoi spriamovanosti dii. Abstract of Doctoral Dissertation for Pharmaceutical Sciences. Kharkiv, 34 p. [In Russian].

Kokhno, M. A. (Ed.), Parkhomenko, L. I., Zarubenko, A. U., et al. (2002). Dendroflora Ukrainy. Dykorosli y kultyvovani dereva $i$ kushchi. (Part 1). Kyiv: Fitosotsiotsentr, 448 p. [In Ukrainian].

Kosenko, I. S. (2002). Lishchyny v Ukraini. Kyiv: Akademperiodyka, 266 p. [In Ukrainian].

Kutsenko, S. A., \& Ruban, O. A. (2013). Doslidzhennia pokaznykiv yakosti likarskoi roslynnoi syrovyny nastoiky "Venoton". Ukrainskyi zhurnal klinichnoi ta laboratornoi medytsyny, 8(2), 49-51. [In Ukrainian].

Lysiuk, R. M., \& Shliakhta, Ya. M. (2014). Tsiliushchi derevni roslyny, (pp. 155-156). Kyiv: Znannia, 260 p. [In Ukrainian].

Mota Ana H. (2016). A Review of Medicinal Plants Used in Therapy of Cardiovascular Diseases. International Journal of Pharmacognosy and Phytochemical Research, 8(4), 572-591.
Movsumov, I. S., Iusifova, D. Iu., \& Garaev, E. A. (2013). Biologicheski aktivnye veshhestva Corylus avellana L., proizrastaiushhei v Azerbaidzhane. Khimiia rastit. syria, 4, 259-261. [In Russian].

Oliveira, I., Sousa, A., Valentao, P., Andrade, P. B., Ferreira, I. C. F. R., Ferreres, F., Bento, A., Seabra, R., Estevinho, L., \& Pereira, J. A. (2007). Hazel (Corylus avellana L.) leaves as source of antimicrobial and antioxidative compounds. Food Chem., 105, 1018-1025. https://doi.org/10.1016/j.foodchem.2007.04.059

Olshanskyi, I. H. (2014). Pidrodyna Coryloideae J. D. Hooker (Betulaceae) u flori Ukrainy. (Part 1). Visnyk Luhanskoho Natsionalnoho Universytetu imeni Tarasa Shevchenka. Biolohichni nauky, 12(295), 62-74. [In Ukrainian].

Ottaggio, L., Bestoso, F., Armirotti, A., Balbi, A., Damonte, G., Mazzei, M., Sancandi, M., \& Miele, M. (2008). Taxanes from Shells and Leaves of Corylus avellana. J. Nat. Prod, 71, 58-60. https://doi.org/10.1021/np0704046

Petkov, V. (Ed.). (1988). Sovremennaia fitoterapiia. Sofia: Meditcina i fizkultura, 504 p. [In Russian].

Popova, N. V., \& Litvinenko, V. I. (2008). Lekarstvennye rasteniia mirovoi flory. Kharkiv: SPDFO, 510 p. [In Russian].

Radev, S., Georgiev, N., Tzaneva, M., \& Sokolova, K. (1997). The hepatoprotective effects of flavonoids isolated from Corylus colurna. Bulg Med, 5, 13-15.

Riethmüller, E. (2016). Recovery of new diarylheptanoid sources in Betulaceae. Characterisation of the phenolic profile of Corylus species by HPLC-ESI-MS methods. Ph.D. Dissertation. Budapest, 147 p.

Rusu, M. A., Bucur, N., Puica, C., \& Tamas, M. (1999). Effects of Corylus avellana in Acetaminophen and CCl4 Induced Toxicosis. Phytother. Res. 13, 120-123.

Rusu, M. A., Tamas, M., Puica, C., Roman, Ioana, \& Sabadas, Mihaela. (2005). The Hepatoprotective Action of Ten Herbal Extracts in CCl4 Intoxicated Liver. Phytother. Res., 19, 744-749. https://doi.org/10.1002/ptr.1625

Shahidi, F., Alasalvar, C., \& Liyana-Pathirana, C. M. (2007). Antioxidant phytochemicals in hazelnut kernel (Corylus avellana L.) and hazelnut byproducts. J. Agric. Food Chem. 55, 3232-13232. https://doi.org/10.1021/jf062472o

Szentmihályi, K., Marczal, G., \& Then, M. (2006). Medicinal plants in view of trace elements. Thaiszia. J. Bot., Košice, 16, 99-107.

Takhtajan, A. L. (2009). Flowering Plants, (2nd ed.). New York: Springer, $871 \mathrm{p}$.

Zhyla, A. S., \& Huz, M. M. (2011). Potentsial nasinnoi bazy lishchyny derevovydnoi na terytorii lisostepovoi zony Ukrainy. Scientific Bulletin of UNFU, 21(4), 50-54. [In Ukrainian].

Zhyla, A. S., \& Huz, M. M. (2012). Vyroshchuvannia lishchyny derevovydnoi. Praktychni rekomendatsii. Lviv: NLTU Ukrainy, 32 p. [In Ukrainian].

Р. Н. Лысюк1, Я. М. Шляхта 2 , В. Я. Шляхта ${ }^{3}$, Р. Е. Дармограй1 , И. В. Коваль'

${ }^{1}$ Львовский национальный медицинский университет им. Данила Галиикого, г. Львов, Украина ${ }^{2}$ Национальный университет "Львовская политехника", г. Львов, Украина

${ }^{3}$ Региональный ландшафтный парк "Знесение", г. Львов, Украина

\section{ЛИСТ ВИДОВ РОДА ЛЕЩИНА КАК ИСТОЧНИК ЦЕННОГО РАСТИТЕЛЬНОГО СЫРЬЯ}

Исследована перспективная растительная субстанция - листья лещины, которые являются важным источником фенольных соединений и таксанов и имеют значительный ресурсный потенциал в Украине. Экстракты природных антиоксидантов, полученные с сопутствующего сырья плодов фундука, могут использоваться как нутрицевтики, пищевые добавки, фармацевтические или косметические субстанции; таксол и таксаны известны как противораковые соединения. Среди около 10 видов рода Лещина, интродуцированных в ботанических садах и дендрологических парках Украины, только 2 оказались перспективными как в ботаническом, так и в фармацевтическом аспектах. Приведены научные данные о ресурсных и морфо-биологических характеристиках лещины обыкновенной и древовидной, их химического состава, фармакологической активности; оценены актуальное состояние и перспективы медицинского применения. Проведен сравнительный анализ эколого-фитоценотических особенностей лещины обыкновенной и лещины древовидной, актуального состояния и перспектив интродукции данных видов в Украине. Представленные научные данные о богатом химическом составе и фармакологической активности листьев лещины свидетельствуют о перспективности дальнейших исследований данного вида лекарственного растительного сырья и могут быть использованы с целью оптимизации их применения при сердечно-сосудистых, гастроэнтерологических и урологических заболеваниях, а также разработки критериев стандартизации.

Ключевые слова: лещина обыкновенная; лещина древовидная; фенольные соединения; активность; применение. 
${ }^{1}$ Danylo Halytsky Lviv National Medical University, Lviv, Ukraine ${ }^{2}$ Lviv Polytechnic National University, Lviv, Ukraine

3 "Znesinnya" Regional Landscape Park, Lviv, Ukraine

\section{LEAVES OF CORYLUS SPP. AS SOURCES OF VALUABLE HERBAL SUBSTANCES}

The work is dedicated to the investigation of a promising herbal substance - hazel leaves (Coryli folia) that is an important source of phenolic compounds and taxanes and has significant resource potential in Ukraine. Extracts of natural antioxidants derived from the accompanying raw materials of hazelnut fruits might be used as nutraceuticals, food supplements, pharmaceutical or cosmetic substances; taxol and taxanes are known as anticancer compounds. In the course of our study we have revealed that amongst about 10 Corylus spp., introduced in the botanical gardens and dendrological parks of Ukraine, only 2 of them are considered as promising both in botanical and pharmaceutical aspects. The scientific data on resources, morphological and biological characteristics, chemical composition, pharmacological activity of Corylus avellana (common hazel) and C. colurna (Turkish hazel) have been presented; the actual state and prospects for medical application of hazel leaves are estimated. A comparative analysis of the ecological and phytocoenic features of common hazel and Turkish hazel, the current state and the prospects for the introduction of these species in Ukraine has been carried out. Therefore, the presented scientific data concerning the rich chemical composition and potent pharmacological activity of Corylus spp. leaves indicate that the further research of the subjected medicinal plant material is promising and can be applied to optimize their use in cardiovascular, gastroenterological and urological diseases, and to work out the standardization criteria for these herbal substances.

Keywords: Common hazel; Turkish hazel; phenolic compounds; activity; application. 